\title{
Analysis of $\beta$-agonists in different biological matrices by liquid chromatography-tandem mass spectrometry
}

\author{
Tomasz Śniegocki ${ }^{\bowtie}$, Bartosz Sell, Andrzej Posyniak \\ Department of Pharmacology and Toxicology, National Veterinary Research Institute, 24-100 Puławy, Poland \\ sniego@piwet.pulawy.pl
}

Received: April 19, $2021 \quad$ Accepted: October 20, 2021

\begin{abstract}
Introduction: Wide use is made of $\beta$-agonists in therapy due to their smooth muscle-relaxant properties. They also have a side effect of increasing muscle mass. Besides improving oxygen utilisation as bronchodilators, $\beta$-agonists increase protein synthesis and promote fat burning. The growth- and performance-enhancing effects are often exploited in illegal use. The guiding objective of this study was to develop a procedure for the determination of $\beta$-agonists by a single method in different types of matrices. Material and Methods: Five grams of homogenised samples were subjected to enzymatic hydrolysis with $\beta$-glucuronidase in ammonium acetate, $\mathrm{pH}$ 5.2. Purification was performed by solid phase extraction. Analytes were eluted with $10 \%$ acetic acid in methanol. The eluted $\beta$-agonists were analysed by high-performance liquid chromatography-tandem mass spectrometry. Results: Validation results met the requirement of the confirmation criteria according to European Commission Decision 2002/657/EC in terms of apparent recoveries (93.2-112.0\%), repeatability (3.1-7.1\%) and intra-laboratory reproducibility (4.1-8.2\%). Conclusion: The method can be successfully applied in the detection and determination of clenbuterol, salbutamol, mabuterol, mapenterol, terbutaline, brombuterol, zilpaterol, isoxsuprine and ractopamine in feed, drinking water, urine, muscle, lung and liver matrices.
\end{abstract}

Keywords: $\beta$-agonists, residues, feed, food products, HPLC-MS/MS.

\section{Introduction}

Beta-agonists are a large group of chemical compounds with a common pharmacological effect of stimulating $\beta$-receptors, mainly in the bronchi (selective $\beta$-receptor agonists). Among these substances, three groups can be distinguished: aniline derivatives (clenbuterol, brombuterol, mabuterol and mapenterol), phenol derivatives (salbutamol, isoxsuprine and ractopamine) and resorcinol derivatives (terbutaline) (8). Some of these substances, are used in the treatment of bronchial asthma due to their spasmolytic properties. A side effect of prolonged use of $\beta$-agonists is muscle mass gain. These $\beta$-agonist actions can be illegally used in humans and animals to accelerate growth and increase muscle mass. In addition, regardless of the degree of selectivity, these drugs cause heart rate acceleration by stimulation of $\beta 2$-receptors in the myocardium and blood vessels, which can cause cardiac arrhythmias, the appearance of sudden ventricular contractions causing loss of consciousness, and at higher doses even death $(9,19,22,24,26,28)$.
Due to adverse side effects, these compounds are not allowed to be used in slaughter animals (6). In Poland, monitoring of $\beta$-agonist residues in food products of animal origin is carried out based on the currently applicable European Community and internal regulations, and as part of a comprehensive program of chemical, biological and veterinary drug residue surveillance $(6,10,11)$.

Residues of $\beta$-agonist substances are mainly detected and confirmed with gas and liquid chromatography methods, typically high-performance liquid chromatography, with tandem mass spectrometry (HPLC-MS/MS) (1, 3, 7, 9, 12, 13, 17, 18, 19, 22, 23, $25,27-30)$. The aim of this study was to develop a method for the detection and determination of clenbuterol, salbutamol, mabuterol, mapenterol, terbutaline, brombuterol, zilpaterol, isoxsuprine and ractopamine in feed, drinking water and animal tissues from different species, i.e. pig, poultry and cattle based on extraction with molecular imprinted polymer (MIP) columns and analysis by liquid chromatography coupled with tandem mass spectrometry. 


\section{Material and Methods}

All reagents were of minimum analytical grade or higher. Materials were procured as follows: ammonium acetate and methanol (LC-MS grade) were from J.T. Baker (Deventer, the Netherlands). Formic acid, solid-phase extraction with molecular imprinted polymer (SPE-MIP) cartridges and $\beta$-glucoronidase were sourced from Sigma-Aldrich Chemie (Steinheim, Germany). Ultrapure water was filtered through a Milli-Q system manufactured by Millipore (Billerica, MA, USA). Nanosep MF $0.22 \mu \mathrm{m}$ filters were supplied by Pall (Port Washington, NY, USA). Ammonia was obtained from POCH (Gliwice, Poland). Clenbuterol, salbutamol, mabuterol, mapenterol, terbutaline, bromobuterol, isoxsuprine, zilpaterol, ractopamine and the internal standards clenbuterol- $\mathrm{D}_{9}$, isoxsuprine- $\mathrm{D}_{5}$, mabuterol- $\mathrm{D}_{9}$, mapenterol- $\mathrm{D}_{11}$, ractopamine- $\mathrm{D}_{6}$, and salbutamol- $\mathrm{D}_{6}$ were purchased from Witega (Berlin, Germany).

HPLC-MS/MS. The HPLC-MS/MS system consisted of an ExionLC HPLC system connected to an API 5500 Qtrap mass spectrometer (AB Sciex, Concord, Canada). Analyst 1.6.3 software controlled the HPLC-MS/MS system and Multiquant 3.2 was used to process the data (AB Sciex). The MS/MS was operated at the following parameters: desolvation temperature was set at $500^{\circ} \mathrm{C}$, gas 1 (air) at 40 psi, gas 2 (air) at 40 psi, collision gas $\left(\mathrm{N}_{2}\right)$ at the high setting, nebuliser gas $\left(\mathrm{N}_{2}\right)$ at $40 \mathrm{psi}$, and curtain gas $\left(\mathrm{N}_{2}\right)$ at 40 psi. The voltages of the electron multiplier and the electrospray capillary were set at 2,100 and 4,500 , respectively. Chromatography was performed in a Kinetex C8(2) column $3 \mu \mathrm{m} \times 2 \mathrm{~mm}, 100 \mathrm{~mm}$ connected to a SecurityGuard ULTRA Kinetex C8 precolumn $3 \mu \mathrm{m} \times 2 \mathrm{~mm}, 4 \mathrm{~mm}$ (both Phenomenex, Torrance, CA, USA). The mobile phase was composed of two solutions: A $(0.1 \%$ formic acid) and $\mathrm{B}$ (methanol) in a gradient which started with $99 \%$ of $\mathrm{A}$ and $1 \%$ of $\mathrm{B}$. From 0 to $2.0 \mathrm{~min}$, the concentration of $\mathrm{B}$ was raised to $20 \%$ and left for $1.0 \mathrm{~min}$. After that, the B concentration was raised to $50 \%$ and left for $2.0 \mathrm{~min}$. Finally, after $0.5 \mathrm{~min}$, it was decreased to $1 \%$ and left for $4 \mathrm{~min}$. The flow rate was $0.4 \mathrm{~mL} / \mathrm{min}$. The column operating temperature was maintained at $15^{\circ} \mathrm{C}$. The ions were monitored in scheduled multiple reaction monitoring (sMRM) mode with an MRM detection window of $40 \mathrm{~s}$ (Table 1$)$.

Table 1. Mass spectrometry parameters for precursor ions and product ion transitions of $\beta$-agonists and internal standards

\begin{tabular}{|c|c|c|c|c|c|}
\hline Analyte & $\begin{array}{l}\text { Retention time } \\
(\mathrm{min})\end{array}$ & $\begin{array}{l}\text { Precursor ion } \\
(\mathrm{m} / \mathrm{z})\end{array}$ & Ion transition & $\begin{array}{c}\text { Declustering } \\
\text { potential }\end{array}$ & $\begin{array}{c}\text { Collision energy } \\
(\mathrm{eV})\end{array}$ \\
\hline Brombuterol & 4.2 & 366.8 & $\begin{array}{l}213.9 \\
292.8\end{array}$ & 56 & $\begin{array}{l}43 \\
47\end{array}$ \\
\hline Clenbuterol & 4.1 & 276.8 & $\begin{array}{l}203.0 \\
132.1\end{array}$ & 76 & $\begin{array}{l}23 \\
47\end{array}$ \\
\hline Isoxsuprine & 4.3 & 302.2 & $\begin{array}{l}150.0 \\
107.0\end{array}$ & 61 & $\begin{array}{l}31 \\
37\end{array}$ \\
\hline Mabuterol & 4.3 & 310.9 & $\begin{array}{l}237.0 \\
217.0\end{array}$ & 20 & $\begin{array}{l}25 \\
35\end{array}$ \\
\hline Mapenterol & 4.5 & 324.9 & $\begin{array}{l}237.0 \\
217.0\end{array}$ & 146 & $\begin{array}{l}25 \\
33\end{array}$ \\
\hline Salbutamol & 3.2 & 239.9 & $\begin{array}{l}148.0 \\
166.1\end{array}$ & 131 & $\begin{array}{l}25 \\
19\end{array}$ \\
\hline Ractopamine & 4.0 & 301.9 & $\begin{array}{l}164.1 \\
136.1\end{array}$ & 16 & $\begin{array}{l}23 \\
31\end{array}$ \\
\hline Terbutaline & 3.2 & 225.9 & $\begin{array}{l}152.1 \\
125.1\end{array}$ & 121 & $\begin{array}{l}23 \\
35\end{array}$ \\
\hline Zilpaterol & 3.1 & 261.9 & $\begin{array}{l}185.0 \\
202.0\end{array}$ & 26 & $\begin{array}{l}35 \\
27\end{array}$ \\
\hline Clebuterol-D 9 & 4.1 & 285.9 & 204.0 & 31 & 25 \\
\hline Isoxsuprine $-\mathrm{D}_{5}$ & 4.3 & 307.2 & 150.0 & 61 & 23 \\
\hline Mabuterol-D 9 & 4.3 & 319.9 & 238.0 & 76 & 25 \\
\hline Mapenterol-D $\mathrm{D}_{11}$ & 4.5 & 335.9 & 238.0 & 76 & 25 \\
\hline Ractopamine- $\mathrm{D}_{6}$ & 4.0 & 308.0 & 168.1 & 56 & 23 \\
\hline Salbutamol-D 6 & 3.2 & 248.9 & 148.0 & 136 & 27 \\
\hline
\end{tabular}

Table 2. Concentration levels used for validation of the $\beta$-agonist detection method in different matrices

\begin{tabular}{|c|c|c|c|c|c|c|}
\hline Analyte & $\begin{array}{c}\text { drinking water } \\
\mu \mathrm{g} \mathrm{kg}^{-1}\end{array}$ & $\begin{array}{c}\text { feed } \\
\mu \mathrm{g} \mathrm{kg}{ }^{-1}\end{array}$ & $\begin{array}{c}\text { liver } \\
\mu \mathrm{g} \mathrm{kg}^{-1}\end{array}$ & $\begin{array}{c}\text { urine } \\
\mu \mathrm{g} \mathrm{kg}^{-1}\end{array}$ & $\begin{array}{l}\text { muscle } \\
\mu \mathrm{g} \mathrm{kg}^{-1}\end{array}$ & $\begin{array}{c}\text { lung } \\
\mu \mathrm{g} \mathrm{kg}^{-1}\end{array}$ \\
\hline Brombuterol & $0.1 ; 0.2 ; 0.4 ; 1.6$ & $2.5 ; 5.0 ; 10.0 ; 40.0$ & $0.1 ; 0.2 ; 0.4 ; 1.6$ & $0.1 ; 0.2 ; 0.4 ; 1.6$ & $0.05 ; 0.1 ; 0.2 ; 0.8$ & $0.1 ; 0.2 ; 0.4 ; 1.6$ \\
\hline Clenbuterol & $0.1 ; 0.2 ; 0.4 ; 1.6$ & $2.5 ; 5.0 ; 10.0 ; 40.0$ & $0.1 ; 0.2 ; 0.4 ; 1.6$ & $0.1 ; 0.2 ; 0.4 ; 1.6$ & $0.05 ; 0.1 ; 0.2 ; 0.8$ & $0.1 ; 0.2 ; 0.4 ; 1.6$ \\
\hline Isoxsuprine & $0.25 ; 0.5 ; 1.0 ; 4.0$ & $2.5 ; 5.0 ; 10.0 ; 40.0$ & $0.25 ; 0.5 ; 1.0 ; 4.0$ & $0.25 ; 0.5 ; 1.0 ; 4.0$ & $0.25 ; 0.5 ; 1.0 ; 4.0$ & $0.25 ; 0.5 ; 1.0 ; 4.0$ \\
\hline Mabuterol & $0.1 ; 0.2 ; 0.4 ; 1.6$ & $2.5 ; 5.0 ; 10.0 ; 40.0$ & $0.1 ; 0.2 ; 0.4 ; 1.6$ & $0.1 ; 0.2 ; 0.4 ; 1.6$ & $0.05 ; 0.1 ; 0.2 ; 0.8$ & $0.1 ; 0.2 ; 0.4 ; 1.6$ \\
\hline Mapenterol & $0.1 ; 0.2 ; 0.4 ; 1.6$ & $2.5 ; 5.0 ; 10.0 ; 40.0$ & $0.1 ; 0.2 ; 0.4 ; 1.6$ & $0.1 ; 0.2 ; 0.4 ; 1.6$ & $0.05 ; 0.1 ; 0.2 ; 0.8$ & $0.1 ; 0.2 ; 0.4 ; 1.6$ \\
\hline Salbutamol & $2.5 ; 5.0 ; 10.0 ; 40.0$ & $2.5 ; 5.0 ; 10.0 ; 40.0$ & $2.5 ; 5.0 ; 10.0 ; 40.0$ & $0.5 ; 1.0 ; 2.0 ; 8.0$ & $2.5 ; 5.0 ; 10.0 ; 40.0$ & $0.5 ; 1.0 ; 2.0 ; 8.0$ \\
\hline Ractopamine & $0.5 ; 1.0 ; 2.0 ; 8.0$ & $2.5 ; 5.0 ; 10.0 ; 40.0$ & $0.5 ; 1.0 ; 2.0 ; 8.0$ & $0.5 ; 1.0 ; 2.0 ; 8.0$ & $0.5 ; 1.0 ; 2.0 ; 8.0$ & $0.5 ; 1.0 ; 2.0 ; 8.0$ \\
\hline Terbutaline & $5.0 ; 10.0 ; 20.0 ; 80.0$ & $2.5 ; 5.0 ; 10.0 ; 40.0$ & $5.0 ; 10.0 ; 20.0 ; 80.0$ & $1.5 ; 3.0 ; 6.0 ; 24.0$ & $5.0 ; 10.0 ; 20.0 ; 80.0$ & $1.5 ; 3.0 ; 6.0 ; 24.0$ \\
\hline Zilpaterol & $2.5 ; 5.0 ; 10.0 ; 40.0$ & $2.5 ; 5.0 ; 10.0 ; 40.0$ & $2.5 ; 5.0 ; 10.0 ; 40.0$ & $0.5 ; 1.0 ; 2.0 ; 8.0$ & $2.5 ; 5.0 ; 10.0 ; 40.0$ & $0.5 ; 1.0 ; 2.0 ; 8.0$ \\
\hline
\end{tabular}


Sample Preparation. Urine, homogenised liver, muscle and lung samples in an amount of $5 \pm 0.05 \mathrm{~g}$ each were mixed with $100 \mu \mathrm{L}$ of the working solution of internal standards. A $5 \mathrm{~mL}$ volume of $0.05 \mathrm{M}$ of acetate buffer ( $\mathrm{pH} 5.2$ ) and $50 \mu \mathrm{L}$ of $\beta$-glucuronidase were added next, and the solution was mixed for approximately $60 \mathrm{~s}$. The samples were hydrolysed by incubating overnight at $37 \pm 3^{\circ} \mathrm{C}$. Subsequently, $5 \mathrm{~mL}$ of $0.1 \mathrm{M}$ acetate buffer ( $\mathrm{pH}$ 6.7) was added and adjusted to $\mathrm{pH} \approx 6.7$ with ammonia or acetic acid. For other matrices (drinking water and feed), $5 \pm 0.05 \mathrm{~g}$ of sample was mixed with $100 \mu \mathrm{L}$ of the working solution of internal standards, then $5 \mathrm{~mL}$ of $0.1 \mathrm{M}$ acetate buffer (pH 6.7) was added and the solution was mixed for $0.5 \mathrm{~min}$ on a vortex mixer at $349 \times \mathrm{rcf}$ and centrifuged at $2,930 \times \operatorname{rcf}$ for $15 \mathrm{~min}$ at $4^{\circ} \mathrm{C}$ before being transferred to the preconditioned SPE-MIP cartridges.

Cleanup. The SPE-MIP cartridges were placed on a vacuum manifold and the cartridges were sequentially conditioned with $1 \mathrm{~mL}$ of methanol, $1 \mathrm{~mL}$ of water, and $1 \mathrm{~mL}$ of acetate buffer. After loading the extract, the cartridges were washed with a mixture of $0.5 \%$ acetic acid in acetonitrile, $50 \mathrm{mM}$ of ammonium acetate ( $\mathrm{pH}$ 6.7), and acetonitrile/water (60/40, v/v). After drying, the substances were eluted with $10 \%$ acetic acid in methanol and then evaporated under a stream of nitrogen in a heating block at $45 \pm 5^{\circ} \mathrm{C}$. After evaporation, the dry residue was dissolved with $200 \mu \mathrm{L}$ of methanol/water mixture $(10 / 90, v / v)$ and filtered through Nanosep MF $0.22 \mu \mathrm{m}$ filters before being placed into an autosampler vial.

Validation criteria. The method was validated according to the recommendations of Commission Decision 2002/657/EC (4), in like manner to previously described methods $(20,21)$. The following statistical parameters of the method were determined for each matrix: selectivity, linearity, repeatability, intralaboratory reproducibility, limit of decision $(\mathrm{CC} \alpha)$ and detection capability $(\mathrm{CC} \beta)$.

The matrix effect was calculated for each of the compounds and each of the matrices at the second concentration level using the same method as previously described (21). The selectivity of the method was tested using reagent samples, blank - urine, liver, drinking water, lung, muscle and feed samples. The linearity of the standard curve was determined in a range depending on the matrix and compounds in question (Table 2). The same levels were used for repeatability, intra-laboratory reproducibility and apparent recovery.

\section{Results}

The procedure presented in the current article is selective and able to detect nine $\beta$-agonists in various matrices like feed, drinking water, urine, muscle and liver in one method (Fig. 1).
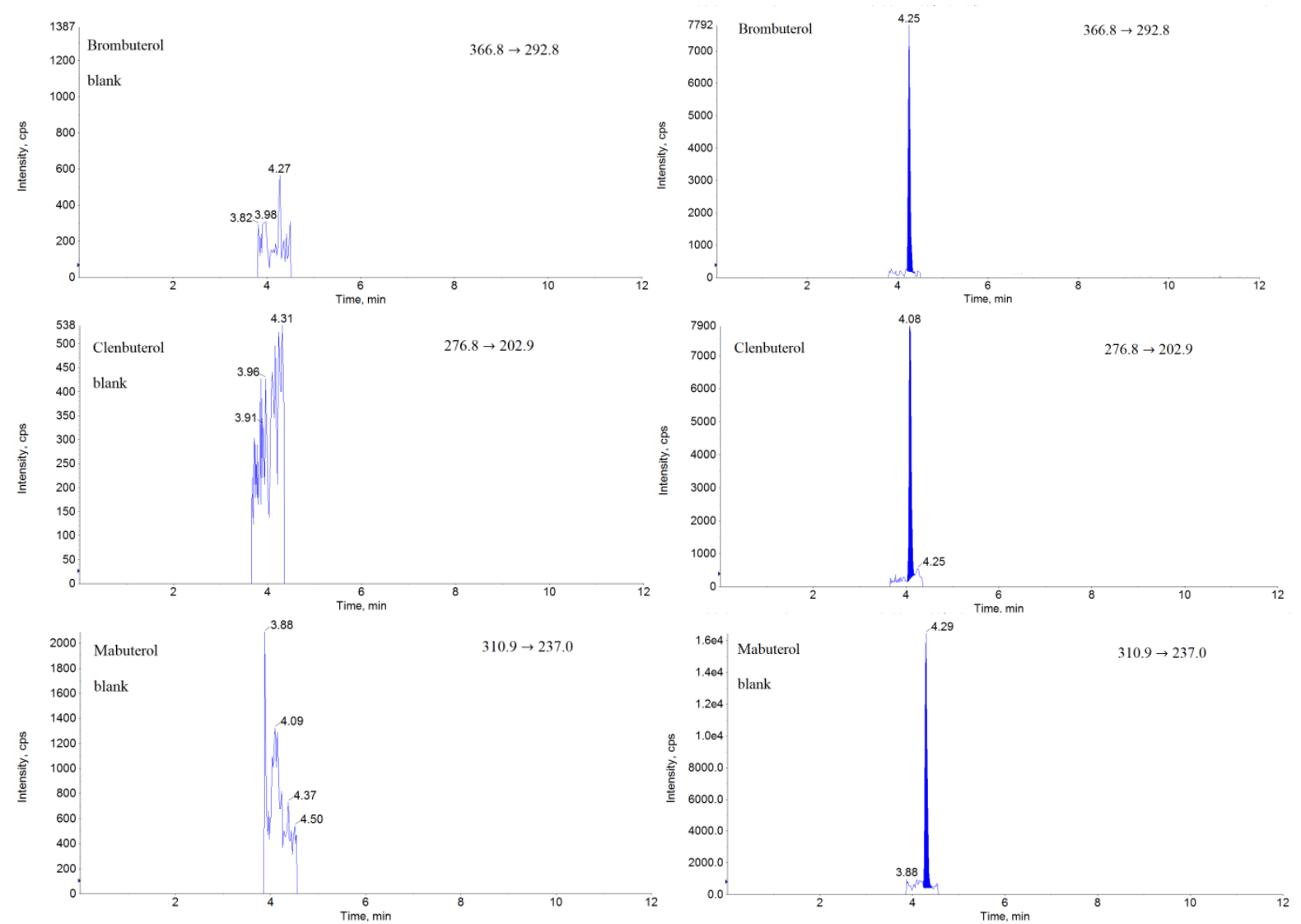

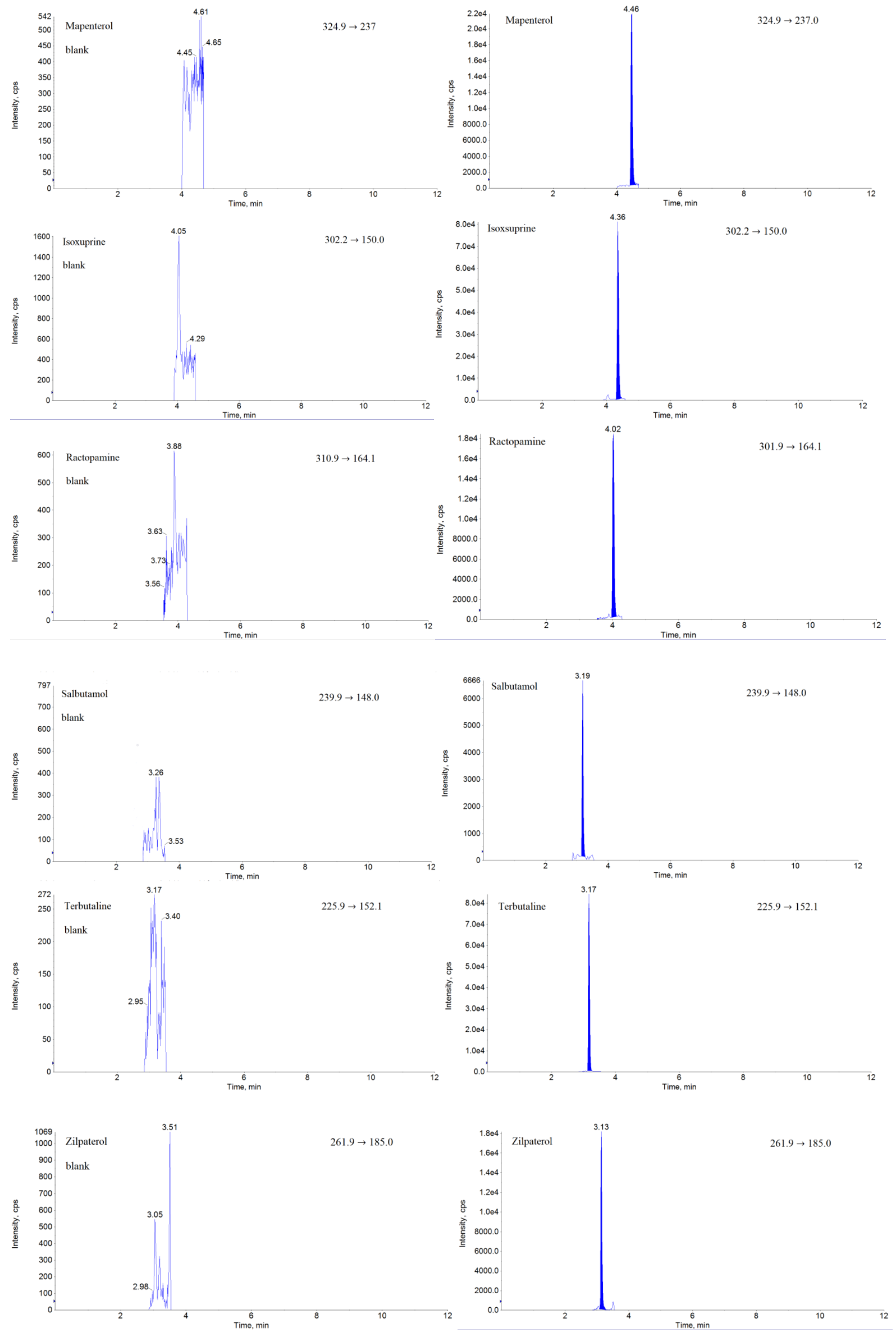

Fig. 1. Chromatograms of blank and spiked lung matrices with $\beta$-agonists at $0.2 \mu \mathrm{g} \mathrm{kg}^{-1}$ for clenbuterol, mabuterol, mapenterol, brombuterol, and at $1.0 \mu \mathrm{g} \mathrm{kg}^{-1}$ for salbutamol and zilpaterol, ractopamine, isoxsuprine, and terbutaline 
Table 3. Validation report for $\beta$-agonists

\begin{tabular}{|c|c|c|c|c|c|c|c|c|}
\hline Matrix & $\begin{array}{l}\text { Repeatability } \\
\left(\mathrm{RSD}_{\mathrm{r}}, \%\right)\end{array}$ & $\begin{array}{l}\text { Within-lab } \\
\text { reproducibility } \\
\left.\text { (RSD } \text { (wR }_{\mathrm{wR}} \%\right)\end{array}$ & $\begin{array}{c}\mathrm{CC} \alpha \\
\left(\mu \mathrm{g} \mathrm{kg}^{-1}\right)\end{array}$ & $\begin{array}{c}\mathrm{CC} \beta \\
\left(\mu \mathrm{g} \mathrm{kg}^{-1}\right)\end{array}$ & $\begin{array}{c}\text { Apparent recovery } \\
\text { (\%) }\end{array}$ & $\begin{array}{l}\text { Concentration } \\
\text { range }(\mathrm{ng} / \mathrm{mL})\end{array}$ & Matrix effect (\%) & $\begin{array}{c}\text { Expanded } \\
\text { uncertainty } \\
\left(\mu \mathrm{g} \mathrm{kg}^{-1}\right)\end{array}$ \\
\hline $\begin{array}{l}\text { drinking water } \\
\text { feed } \\
\text { liver } \\
\text { urine } \\
\text { muscle } \\
\text { lung }\end{array}$ & $\begin{array}{l}4.1 \pm 3.8 \\
6.2 \pm 4.6 \\
4.3 \pm 4.1 \\
4.6 \pm 3.7 \\
5.9 \pm 6.5 \\
4.3 \pm 3.8\end{array}$ & $\begin{array}{l}4.5 \pm 4.0 \\
5.6 \pm 6.1 \\
5.1 \pm 4.7 \\
5.3 \pm 4.4 \\
4.5 \pm 7.6 \\
4.8 \pm 4.6 \\
\end{array}$ & $\begin{array}{l}0.10 \\
2.50 \\
0.10 \\
0.10 \\
0.05 \\
0.10 \\
\end{array}$ & $\begin{array}{l}0.11 \\
2.70 \\
0.12 \\
0.11 \\
0.06 \\
0.11\end{array}$ & $\begin{array}{c}\text { Clenbuterol } \\
103.9 \pm 4.3 \\
104.5 \pm 6.8 \\
103.5 \pm 6.2 \\
102.6 \pm 5.1 \\
109.1 \pm 4.4 \\
96.1 \pm 4.9 \\
\end{array}$ & $\begin{array}{c}0.1-1.6 \\
2.5-40.0 \\
0.1-1.6 \\
0.1-1.6 \\
0.1-1.6 \\
0.1-1.6 \\
\end{array}$ & $\begin{array}{l}4.3 \pm 3.9 \% \\
5.0 \pm 3.9 \% \\
6.1 \pm 3.2 \% \\
5.6 \pm 2.7 \% \\
4.3 \pm 6.5 \% \\
5.3 \pm 4.9 \% \\
\end{array}$ & $\begin{array}{l}0.20 \pm 0.02 \\
5.00 \pm 1.14 \\
0.20 \pm 0.06 \\
0.20 \pm 0.04 \\
0.10 \pm 0.02 \\
0.20 \pm 0.05\end{array}$ \\
\hline $\begin{array}{l}\text { drinking water } \\
\text { feed } \\
\text { liver } \\
\text { urine } \\
\text { muscle } \\
\text { lung }\end{array}$ & $\begin{array}{l}3.7 \pm 3.6 \\
5.6 \pm 5.4 \\
5.9 \pm 5.8 \\
5.2 \pm 4.9 \\
6.3 \pm 4.1 \\
5.9 \pm 3.9\end{array}$ & $\begin{array}{l}4.7 \pm 3.9 \\
6.7 \pm 5.6 \\
7.3 \pm 6.3 \\
6.3 \pm 5.1 \\
6.4 \pm 5.0 \\
6.6 \pm 5.6 \\
\end{array}$ & $\begin{array}{l}0.10 \\
2.50 \\
0.10 \\
0.10 \\
0.05 \\
0.10 \\
\end{array}$ & $\begin{array}{l}0.11 \\
2.62 \\
0.12 \\
0.11 \\
0.06 \\
0.11\end{array}$ & $\begin{array}{c}\text { Mabuterol } \\
99.5 \pm 4.8 \\
106.2 \pm 7.8 \\
95.4 \pm 7.3 \\
103.0 \pm 4.1 \\
95.9 \pm 6.0 \\
93.2 \pm 4.6\end{array}$ & $\begin{array}{c}0.1-1.6 \\
2.5-40.0 \\
0.1-1.6 \\
0.1-1.6 \\
0.05-0.8 \\
0.1-1.6 \\
\end{array}$ & $\begin{array}{l}4.0 \pm 3.5 \% \\
6.0 \pm 3.3 \% \\
6.3 \pm 5.2 \% \\
5.4 \pm 4.9 \% \\
5.8 \pm 5.0 \% \\
6.3 \pm 4.6 \% \\
\end{array}$ & $\begin{array}{l}0.20 \pm 0.03 \\
5.00 \pm 1.25 \\
0.20 \pm 0.05 \\
0.20 \pm 0.04 \\
0.10 \pm 0.02 \\
0.20 \pm 0.04\end{array}$ \\
\hline $\begin{array}{l}\text { drinking water } \\
\text { feed } \\
\text { liver } \\
\text { urine } \\
\text { muscle } \\
\text { lung }\end{array}$ & $\begin{array}{l}3.2 \pm 3.4 \\
5.4 \pm 4.6 \\
5.4 \pm 5.0 \\
5.3 \pm 4.5 \\
4.1 \pm 3.4 \\
3.9 \pm 3.7\end{array}$ & $\begin{array}{l}4.1 \pm 4.0 \\
5.6 \pm 7.1 \\
6.4 \pm 5.2 \\
5.4 \pm 4.9 \\
5.0 \pm 4.2 \\
5.4 \pm 4.8\end{array}$ & $\begin{array}{l}0.10 \\
2.50 \\
0.10 \\
0.20 \\
0.05 \\
0.10 \\
\end{array}$ & $\begin{array}{l}0.12 \\
2.61 \\
0.12 \\
0.12 \\
0.06 \\
0.11\end{array}$ & $\begin{array}{c}\text { Mapenterol } \\
98.9 \pm 4.8 \\
105.1 \pm 5.6 \\
93.3 \pm 5.6 \\
102.0 \pm 5.5 \\
97.0 \pm 5.3 \\
100.3 \pm 6.1 \\
\end{array}$ & $\begin{array}{c}0.1-1.6 \\
2.5-40.0 \\
0.1-1.6 \\
0.1-1.6 \\
0.05-0.8 \\
0.1-1.6 \\
\end{array}$ & $\begin{array}{l}4.0 \pm 2.0 \% \\
5.1 \pm 2.9 \% \\
5.4 \pm 4.9 \% \\
4.9 \pm 5.1 \% \\
5.5 \pm 4.1 \% \\
4.8 \pm 5.2 \% \\
\end{array}$ & $\begin{array}{l}0.10 \pm 0.02 \\
5.00 \pm 1.14 \\
0.20 \pm 0.04 \\
0.20 \pm 0.04 \\
0.10 \pm 0.02 \\
0.20 \pm 0.05\end{array}$ \\
\hline $\begin{array}{l}\text { drinking water } \\
\text { feed } \\
\text { liver } \\
\text { urine } \\
\text { muscle } \\
\text { lung }\end{array}$ & $\begin{array}{l}3.1 \pm 3.3 \\
5.6 \pm 4.1 \\
4.9 \pm 4.7 \\
4.5 \pm 3.9 \\
4.6 \pm 4.7 \\
4.9 \pm 3.5\end{array}$ & $\begin{array}{l}4.2 \pm 4.1 \\
6.2 \pm 4.0 \\
5.3 \pm 4.9 \\
5.1 \pm 4.1 \\
5.4 \pm 4.8 \\
5.4 \pm 4.6\end{array}$ & $\begin{array}{l}0.10 \\
2.50 \\
0.10 \\
0.10 \\
0.05 \\
0.10\end{array}$ & $\begin{array}{l}0.12 \\
2.67 \\
0.11 \\
0.11 \\
0.06 \\
0.12\end{array}$ & $\begin{array}{c}\text { Brombuterol } \\
95.4 \pm 4.3 \\
103.2 \pm 6.8 \\
96.5 \pm 6.8 \\
99.6 \pm 5.2 \\
105.4 \pm 5.4 \\
98.2 \pm 4.9\end{array}$ & $\begin{array}{c}0.1-1.6 \\
2.5-40.0 \\
0.1-1.6 \\
0.1-1.6 \\
0.05-0.8 \\
0.1-1.6\end{array}$ & $\begin{array}{l}4.0 \pm 3.6 \% \\
5.3 \pm 3.9 \% \\
6.1 \pm 4.8 \% \\
5.1 \pm 4.6 \% \\
4.5 \pm 5.3 \% \\
5.3 \pm 3.6 \%\end{array}$ & $\begin{array}{l}0.20 \pm 0.05 \\
5.00 \pm 1.24 \\
0.20 \pm 0.05 \\
0.20 \pm 0.04 \\
0.10 \pm 0.03 \\
0.20 \pm 0.05\end{array}$ \\
\hline $\begin{array}{l}\text { drinking water } \\
\text { feed } \\
\text { liver } \\
\text { urine } \\
\text { muscle } \\
\text { lung }\end{array}$ & $\begin{array}{l}3.1 \pm 3.7 \\
4.4 \pm 3.1 \\
4.0 \pm 4.3 \\
4.2 \pm 3.8 \\
4.6 \pm 4.9 \\
4.9 \pm 4.5\end{array}$ & $\begin{array}{l}4.6 \pm 3.6 \\
5.6 \pm 4.6 \\
4.6 \pm 4.9 \\
5.3 \pm 4.2 \\
5.4 \pm 5.3 \\
5.4 \pm 4.9\end{array}$ & $\begin{array}{l}0.50 \\
2.50 \\
0.50 \\
0.50 \\
0.50 \\
0.50 \\
\end{array}$ & $\begin{array}{l}0.57 \\
2.56 \\
0.52 \\
0.52 \\
0.52 \\
0.56 \\
\end{array}$ & $\begin{array}{l}\text { Ractopamine } \\
103.5 \pm 3.9 \\
102.3 \pm 5.2 \\
103.6 \pm 6.8 \\
102.8 \pm 5.1 \\
105.0 \pm 4.7 \\
103.8 \pm 4.3 \\
\end{array}$ & $\begin{array}{c}0.5-8.0 \\
2.5-40.0 \\
0.5-8.0 \\
0.5-8.0 \\
0.5-8.0 \\
0.5-8.0 \\
\end{array}$ & $\begin{array}{l}3.9 \pm 4.1 \% \\
6.0 \pm 3.2 \% \\
5.3 \pm 6.0 \% \\
5.8 \pm 5.3 \% \\
6.5 \pm 5.7 \% \\
5.5 \pm 3.9 \%\end{array}$ & $\begin{array}{l}1.00 \pm 0.23 \\
5.00 \pm 1.35 \\
1.00 \pm 0.26 \\
1.00 \pm 0.23 \\
1.00 \pm 0.16 \\
1.00 \pm 0.26\end{array}$ \\
\hline $\begin{array}{l}\text { drinking water } \\
\text { feed } \\
\text { liver } \\
\text { urine } \\
\text { muscle } \\
\text { lung }\end{array}$ & $\begin{array}{l}4.2 \pm 2.4 \\
5.9 \pm 4.6 \\
5.3 \pm 4.7 \\
4.9 \pm 4.8 \\
5.2 \pm 3.3 \\
4.9 \pm 4.5 \\
\end{array}$ & $\begin{array}{l}5.4 \pm 4.0 \\
6.5 \pm 6.6 \\
7.4 \pm 5.2 \\
6.4 \pm 4.9 \\
5.7 \pm 4.3 \\
5.0 \pm 4.6 \\
\end{array}$ & $\begin{array}{l}2.50 \\
2.50 \\
2.50 \\
0.50 \\
2.50 \\
0.50 \\
\end{array}$ & $\begin{array}{l}2.54 \\
2.72 \\
2.61 \\
0.52 \\
2.61 \\
0.52 \\
\end{array}$ & $\begin{array}{c}\text { Salbutamol } \\
104.9 \pm 4.8 \\
105.1 \pm 6.9 \\
93.3 \pm 5.6 \\
97.0 \pm 6.3 \\
105.3 \pm 4.6 \\
101.5 \pm 5.1 \\
\end{array}$ & $\begin{array}{c}2.5-40.0 \\
2.5-40.0 \\
2.5-40.0 \\
0.5-8.0 \\
2.5-40.0 \\
0.5-8.0 \\
\end{array}$ & $\begin{array}{l}5.3 \pm 3.1 \% \\
6.0 \pm 4.1 \% \\
6.5 \pm 5.4 \% \\
5.4 \pm 5.5 \% \\
6.5 \pm 6.5 \% \\
4.8 \pm 5.6 \% \\
\end{array}$ & $\begin{array}{l}5.00 \pm 1.25 \\
5.00 \pm 1.31 \\
5.00 \pm 1.45 \\
1.00 \pm 0.25 \\
5.00 \pm 1.16 \\
1.00 \pm 0.33\end{array}$ \\
\hline $\begin{array}{l}\text { drinking water } \\
\text { feed } \\
\text { liver } \\
\text { urine } \\
\text { muscle } \\
\text { lung }\end{array}$ & $\begin{array}{l}3.2 \pm 2.4 \\
4.1 \pm 4.5 \\
6.4 \pm 5.7 \\
7.1 \pm 4.3 \\
5.1 \pm 4.3 \\
4.0 \pm 3.5\end{array}$ & $\begin{array}{l}4.1 \pm 3.0 \\
5.9 \pm 4.6 \\
7.7 \pm 6.2 \\
8.0 \pm 4.9 \\
5.9 \pm 4.8 \\
8.2 \pm 7.6\end{array}$ & $\begin{array}{l}2.50 \\
2.50 \\
2.50 \\
0.50 \\
2.50 \\
0.50 \\
\end{array}$ & $\begin{array}{l}2.58 \\
2.73 \\
2.79 \\
0.56 \\
2.69 \\
0.56 \\
\end{array}$ & $\begin{array}{r}\text { Zilpaterol } \\
105.4 \pm 4.8 \\
104.5 \pm 6.3 \\
107.3 \pm 5.6 \\
100.3 \pm 6.8 \\
112.0 \pm 6.1 \\
106.4 \pm 5.3 \\
\end{array}$ & $\begin{array}{c}2.5-40.0 \\
2.5-40.0 \\
2.5-40.0 \\
0.5-8.0 \\
2.5-40.0 \\
0.5-8.0 \\
\end{array}$ & $\begin{array}{l}3.0 \pm 2.1 \% \\
5.3 \pm 3.9 \% \\
6.3 \pm 6.3 \% \\
5.3 \pm 4.6 \% \\
7.3 \pm 5.5 \% \\
7.0 \pm 4.3 \%\end{array}$ & $\begin{array}{l}5.00 \pm 1.19 \\
5.00 \pm 1.40 \\
5.00 \pm 1.52 \\
1.00 \pm 0.23 \\
5.00 \pm 1.64 \\
1.00 \pm 0.45\end{array}$ \\
\hline $\begin{array}{l}\text { drinking water } \\
\text { feed } \\
\text { liver } \\
\text { urine } \\
\text { muscle } \\
\text { lung }\end{array}$ & $\begin{array}{l}5.2 \pm 4.4 \\
6.2 \pm 3.6 \\
4.2 \pm 4.7 \\
6.1 \pm 4.2 \\
3.4 \pm 3.2 \\
5.2 \pm 3.5\end{array}$ & $\begin{array}{l}6.0 \pm 4.5 \\
7.6 \pm 3.9 \\
6.1 \pm 5.7 \\
7.3 \pm 5.0 \\
4.2 \pm 3.6 \\
6.0 \pm 4.0\end{array}$ & $\begin{array}{l}5.00 \\
2.50 \\
5.00 \\
1.50 \\
5.00 \\
1.50 \\
\end{array}$ & $\begin{array}{l}5.34 \\
2.70 \\
5.25 \\
1.54 \\
5.63 \\
1.64 \\
\end{array}$ & $\begin{array}{c}\text { Terbutaline } \\
106.9 \pm 3.8 \\
107.5 \pm 7.1 \\
93.3 \pm 5.1 \\
102.0 \pm 6.5 \\
105.3 \pm 3.8 \\
96.3 \pm 5.1 \\
\end{array}$ & $\begin{array}{l}5.0-80.0 \\
2.5-40.0 \\
5.0-80.0 \\
1.5-24.0 \\
5.0-80.0 \\
1.5-24.0 \\
\end{array}$ & $\begin{array}{l}5.1 \pm 4.6 \% \\
6.6 \pm 4.3 \% \\
5.7 \pm 6.1 \% \\
8.8 \pm 4.7 \% \\
3.5 \pm 3.5 \% \\
6.3 \pm 6.2 \% \\
\end{array}$ & $\begin{array}{c}10.00 \pm 3.60 \\
5.00 \pm 1.72 \\
10.00 \pm 3.12 \\
3.00 \pm 0.86 \\
10.00 \pm 4.1 \\
3.00 \pm 0.82\end{array}$ \\
\hline $\begin{array}{l}\text { drinking water } \\
\text { feed } \\
\text { liver } \\
\text { urine } \\
\text { muscle } \\
\text { lung }\end{array}$ & $\begin{array}{l}3.6 \pm 4.3 \\
3.6 \pm 3.7 \\
3.8 \pm 4.0 \\
4.9 \pm 3.8 \\
3.6 \pm 3.8 \\
3.6 \pm 4.5 \\
\end{array}$ & $\begin{array}{l}4.4 \pm 5.1 \\
4.6 \pm 4.0 \\
4.9 \pm 5.2 \\
5.4 \pm 4.5 \\
4.3 \pm 4.1 \\
5.8 \pm 5.6 \\
\end{array}$ & $\begin{array}{l}0.25 \\
2.50 \\
0.25 \\
0.25 \\
0.25 \\
0.25 \\
\end{array}$ & $\begin{array}{l}0.27 \\
2.59 \\
0.26 \\
0.26 \\
0.26 \\
0.27 \\
\end{array}$ & $\begin{array}{c}\text { Isoxsuprine } \\
102.9 \pm 4.9 \\
104.5 \pm 2.8 \\
102.3 \pm 4.3 \\
106.2 \pm 4.6 \\
98.0 \pm 4.3 \\
108.0 \pm 6.2 \\
\end{array}$ & $\begin{array}{l}0.25-4.0 \\
2.5-40.0 \\
0.25-4.0 \\
0.25-4.0 \\
0.25-4.0 \\
0.25-4.0 \\
\end{array}$ & $\begin{array}{l}3.2 \pm 2.3 \% \\
5.0 \pm 4.9 \% \\
4.6 \pm 4.5 \% \\
5.3 \pm 4.0 \% \\
4.5 \pm 3.5 \% \\
4.3 \pm 5.0 \% \\
\end{array}$ & $\begin{array}{l}0.50 \pm 0.09 \\
5.00 \pm 1.19 \\
0.50 \pm 0.11 \\
0.50 \pm 0.12 \\
0.50 \pm 0.08 \\
0.50 \pm 0.12 \\
\end{array}$ \\
\hline
\end{tabular}


The correlation coefficient of the standard curves prepared with the fortified samples for each $\beta$-agonist was $\geq 0.95$. Depending on the $\beta$-agonist and matrix assayed, the coefficients of variation of repeatability for fortified samples were in a $6.8-11.3 \%$ range, while the range for reproducibility was $8.5-14.2 \%$. The average apparent recovery was $93.2-112.0 \%$. Determination of $\mathrm{CC} \alpha$ and $\mathrm{CC} \beta$ was according to Commission Decision $2002 / 657 / \mathrm{EC}$; the former was in the range of $0.05-5.00 \mu \mathrm{g} \mathrm{kg}^{-1}$ and the latter $0.06-5.63 \mu \mathrm{g} \mathrm{kg}^{-1}$ depending on the compound and the matrix. The expanded uncertainty was calculated for each compound and each of the matrices at the second concentration level applying a coverage factor of 2 , which provided a level of confidence of approximately 95\% (Table 3). The calculated ion suppression of the matrix effects for $\beta$-agonists in all matrices did not exceed $15 \%$.

\section{Discussion}

In this article we describe a method that allows parallel detection and determination of $\beta$-agonist residues in urine, liver, muscle, and lung tissue, feed, and drinking water in a single analytical run. The first step in the development of the method was the selection of chromatographic conditions, which was the optimisation of the conditions for analysis by liquid chromatography coupled with mass spectrometry. Electrospray (ESI) and atmospheric pressure chemical ionisation (APCI) were tested as alternatives, and the electrospray mode was selected for further use due to its higher reproducibility, selectivity, and sensitivity, which was were also confirmed by other authors $(12,13,15,18,25,29,30)$.

With gradient elution, adequate separation of analytes from matrix interfering components was achieved. The selection of chromatographic conditions was based on the publications of other researchers $(3,15)$. The main step of the analytical method is the development of the isolation of analytes from the sample of biological material. The most important stages of analyte isolation in the whole analytical procedure are extraction and purification. After preliminary studies, the extraction method proposed by Boyd et al. (2), Leyssens et al. (16) and Hooijerink et al. (14) was abandoned and purification by liquid-solid extraction was investigated. From the obtained results it was found that all the cartridges selected for the study gave comparable recoveries, but the use of MIP columns yielded higher extract purity, required shorter analysis time (below $12 \mathrm{~min}$ ), and ensured good result.

Simultaneously, studies were conducted on the effect of chemical and enzymatic hydrolysis on the recoveries of the analysed compounds. It was observed that the use of the hydrolysis step allows the release of salbutamol and salbutamol-like compounds from bonds with endogenous matrix components, which was observed in urine, muscle, lung and liver samples. In our procedure, enzymatic hydrolysis was chosen due to its simplicity. This is in agreement with reports in the literature $(2,3,9,14,16)$.

A study comparing different methods for the isolation of analytes from biological material showed that the developed method provided good recovery for the $\beta$-agonists under investigation and, at the same time, sample processing was not very labour- and timeconsuming, which prompted its validation. The validation parameters show that the method meets the appropriate acceptance criteria set by the European Union (4).

The obtained validation results presented above confirm the suitability of the method for conducting routine residue monitoring of these compounds in all presented matrices in the National Monitoring Plan in Poland.

Conflict of Interests Statement: The authors declare that there is no conflict of interests regarding the publication of this article.

Financial Disclosure Statement: This study was supported by the Polish Ministry of Agriculture and Rural Development.

Animal Rights Statement: None required.

\section{References}

1. Beucher L., Dervilly-Pinel G., Prévost S., Monteau F., Le Bizec B. Determination of a large set of $\beta$-adrenergic agonists in animal matrices based on ion mobility and mass separations. Anal Chem 2015, 87, 9234-9242, doi: 10.1021/acs.analchem.5b01831.

2. Boyd D., O’Keefe M., Smyth M.R.: Matrix solid-phase dispersion as a multiresidue extraction technique for $\beta$-agonists in bovine liver tissue. Analyst 1994, 119, 1467-1470, doi: 10.1039/ AN9941901467.

3. Cai J., Henion J.: Quantitative multi-residue determination of $\beta$-agonists in bovine urine using on-line immunoaffinity extraction-coupled column packed capillary liquid chromatography-tandem mass spectrometry. J Chromatogr B 1997, 691, 357-370, doi: 10.1016/S0378-4347(96)00433-1.

4. Commission of the European Communities: Commission Decision 2002/657/EC of 12 August 2002 implementing Council Directive 96/23/EC concerning the performance of analytical methods and the interpretation of results. OJ L 221, 17/8/2002, 8-36.

5. Council of the European Communities: Regulation (EEC) 2377/90 of 26 June 1990 laying down a Community procedure for the establishment of maximum residue limits of veterinary medicinal products in foodstuffs of animal origin. O J L 1990, 18/08/1990, 224, 1-124

6. Council of the European Union: Council Directive 96/23/EC of 29 April 1996 on measures to monitor certain substances and residues thereof in live animals and animal products and repealing Directives 85/358/EEC and 86/469/EEC and Decisions 89/187/EEC and 91/664/EEC. O J L 1996, 23/05/1996, 125, $10-32$

7. Decheng S., Peilong W., Yang L., Ruiguo W., Xia F., Xiaoou S.: Evaluation of $\beta$-agonists in blood meal: Validation of determination method and potential pathway for reentry into the environment. J Chromatogr A 2020, 1612, 460624, doi: 10.1016/j.chroma.2019.460624. 
8. dos Ramos F.J.: $\beta_{2}$-Agonist extraction procedures for chromatographic analysis. J Chromatogr A 2000, 880, 69-83, doi: 10.1016/S0021-9673(00)00240-5.

9. Dumasia M.C., Houghton E.: Screening and confirmatory analysis of $\beta$-agonists, $\beta$-antagonists and their metabolites in horse urine by capillary gas chromatography-mass spectrometry. J Chromatogr B 1991, 564, 503-513, doi: 10.1016/03784347(91)80519-I.

10. European Parliament and Council of the European Union: Regulation (EC) No 882/2004 of the European Parliament and of the Council of 29 April 2004 on official controls performed to ensure the verification of compliance with feed and food law, animal health and animal welfare rules 2004. OJ L 165 , 30/04/2004, 1-141.

11. Government of the Republic of Poland: Ordinance of the Minister of Agriculture and Rural Development of 28 July 2006 on handling prohibited substances, chemical residues, biological residues, medicinal products and radioactive contamination in animals and animal products Dz U 2006, 147, poz. 1067 (Official Journal of Laws 2006, 147, item 1067).

12. Gressler V., Feddern V., de Oliveira Peixoto J., Corrêa Ledur M., Dalla Costa O.A., Mello Monteiro de Lima G.J.: Application of Enzyme Digestion and Deconjugation Followed by Quick, Easy, Cheap, Effective, Rugged, Safe Extraction and Liquid Chromatography-Tandem Mass Spectrometry Methodology To Determine Ractopamine Residue in Pork. J Food Prot 2018, 81, 1258-1263, doi: 10.4315/0362-028X.JFP-17-526.

13. Guo P., Wan J., Zhan C., Zhu C., Jiang W., Ke Y., Ding S., Wang D.: A simplified sample pretreatment for the rapid determination of $22 \beta$-agonist residues in swine muscle and liver tissues by ultra-high-performance liquid chromatography tandem mass spectrometry. J Chromatogr B 2018, 1096, 122-134, doi: 10.1016/j.jchromb.2018.07.038.

14. Hooijerink H., Schilt R., van Bennekom E.O., Huf F.A.: Determination of $\beta$-sympathomimetics in liver and urine by immunoaffinity chromatography and gas chromatography-massselective detection. J Chromatogr B 1994, 660, 303-313, doi: 10.1016/S0378-4347(94)80016-2.

15. Lee H.-B., Sarafin K., Peart T.E.: Determination of $\beta$-blockers and $\beta_{2}$-agonists in sewage by solid-phase extraction and liquid chromatography-tandem mass spectrometry. J Chromatogr A 2007, 1148, 158-167, doi: 10.1016/j.chroma.2007.03.024.

16. Leyssens L., Driessen C., Jacobs A., Czech J., Raus J.: Determination of $\beta 2$-receptor agonists in bovine urine and liver by gas chromatography-tandem mass spectrometry. J Chromatogr B 1991, 564, 515-527, doi: 10.1016/0378-4347(91)80520-M.

17. Liu H., Gan N., Chen Y., Ding Q., Huang J., Lin S., Cao Y., Li T.: Novel method for the rapid and specific extraction of multiple $\beta 2$ agonist residues in food by tailor-made Monolith-MIPs extraction disks and detection by gas chromatography with mass spectrometry. J Sep Sci 2016, 39, 3578-3585, doi: 10.1002/jssc. 201600479 .

18. Liu H., Lin X., Lin T., Zhang Y., Luo Y., Li Q.: Magnetic molecularly imprinted polymers for the determination of $\beta$-agonist residues in milk by ultra high performance liquid chromatography with tandem mass spectrometry. J Sep Sci 2016, 39, 3594-3601, doi: $10.1002 /$ jssc. 201600613
19. Śniegocki T., Posyniak A., Żmudzki J.: Improved gas chromatography-mass spectrometry method for the determination of clenbuterol and salbutamol in animal urine. Bull Vet Inst Pulawy 2005, 49, 443-447.

20. Śniegocki T., Sell B., Giergiel M., Posyniak A.: New method of analysis of nitrofurans and nitrofuran metabolites in different biological matrices using UHPLC-MS/MS. J Vet Res 2018, 62, 161-166, doi: 10.2478/jvetres-2018-0025.

21. Śniegocki T., Sell B., Giergiel M., Posyniak A.: QuEChERS and HPLC-MS/MS Combination for the Determination of Chloramphenicol in Twenty Two Different Matrices. Molecules 2019, 24, 384, doi: 10.3390/molecules24030384.

22. Śniegocki T., Żmudzki J., Posyniak A., Semeniuk S.: Gas chromatography-mass spectrometric confirmatory method for the determination of clenbuterol residues in animal urine and liver samples. Bull Vet Inst Pulawy 2003, 47, 139-144.

23. Tang J., Wang J., Shi S., Hu S., Yuan L.: Determination of $\beta$-Agonist Residues in Animal-Derived Food by a Liquid Chromatography-Tandem Mass Spectrometric Method Combined with Molecularly Imprinted Stir Bar Sorptive Extraction. J Anal Methods Chem 2018, 2018, 9053561, doi: 10.1155/2018/9053561.

24. Traynor I.M., Crooks S.R.H., Bowers J., Elliott C.T.: Detection of multi- $\beta$-agonist residues in liver matrix by use of a surface plasma resonance biosensor. Anal Chim Acta 2003, 483, 187-191, doi: 10.1016/S0003-2670(03)00256-3

25. Wang P., Liu X., Su X., Zhu R.: Sensitive detection of $\beta$-agonists in pork tissue with novel molecularly imprinted polymer extraction followed liquid chromatography coupled tandem mass spectrometry detection. Food Chem 2015, 184, 72-79, doi: 10.1016/j.foodchem.2015.03.073.

26. Witkamp R.: The use of $\beta 2$-agonists as growth promoters in food species. Toxicological aspects and possible health risks to the consumer. In: Scientific Conference on Growth Promotion in Meat Production - Proceedings, Office for Official Publications of the European Communities, Luxembourg, 1996, pp 297-323.

27. Zhang Z., Yan H., Cui F., Yun H., Chang X., Li J., Liu X., Yang L., Hu Q.: Analysis of multiple $\beta$-agonist and $\beta$-blocker residues in porcine muscle using improved QuEChERS Method and UHPLC-LTQ Qrbitrap mass spectrometry. Food Anal Methods 2016, 9, 915-924, doi: 10.1007/s12161-015-0238-z.

28. Zhang X.Z., Gan Y.R., Zhao F.N.: Determination of clenbuterol in pig liver by high-performance liquid chromatography with a coulometric electrode array system. Anal Chim Acta 2004, 489, 95-101, doi: 10.1016/S0003-2670(03)00707-4.

29. Zhu Y., Xie S., Chen D., Pan Y., Qu W., Wang X., Liu Z., Peng D., Huang L., Tao Y., Yuan Z.: Targeted analysis and determination of $\beta$-agonists, hormones, glucocorticoid and psychiatric drugs in feed by liquid chromatography with electrospray ionization tandem mass spectrometry. J Sep Sci 2016, 39, 2584-2594, doi: 10.1002/jssc.201600011.

30. Yikilmaz Y., Kuzukiran O., Erdoğan E., Şen F., Kirmizibayrak O., Filazi A.: The determination of $\beta$-agonist residues in bovine tissues using liquid chromatography-tandem mass spectrometry. Biomed Chromatogr 2020, 34, e4926, doi: 10.1002/bmc.4926. 